\title{
Nitrogen and Zinc Interaction Improves Yield and Quality of Submerged Basmati Rice (Oryza sativa L.)
}

\author{
Hakoomat ALI ${ }^{1}$, Zuhair HASNAIN ${ }^{1}$, Ahmad N. SHAHZAD ${ }^{1 *}$, Naeem SARWAR ${ }^{1}$, \\ Muhammad K. QURESHI ${ }^{2}$, Shazia KHALIQ ${ }^{3}$, Muhammad F. QAYYUM ${ }^{4}$ \\ ${ }^{1}$ Bahauddin Zakariya University, Department of Agronomy, Faculty of Agricultural Sciences and Technology, Multan, 60800 Pakistan; hha94@bzu.edu.pk; \\ z.hasnain@irri.org; anaeems@gmail.com(*correspondingauthor);bajwa834@gmail.com \\ ${ }^{2}$ Bahauddin Zakariya University, Department of Plant Breeding and Genetics, Faculty of Agricultural Sciences and Technology, Multan, 60800 \\ Pakistan;m.k.qureshi81@gmail.com \\ 33ahauddin Zakariya University, Department of Environmental Sciences, Multan,60800 Pakistan; humza38@hotmail.com \\ ${ }^{4}$ Bahauddin Zakariya University,Department of Soil Science, Multan,60800 Pakistan; farooq.qayyum@bzu.edu.pk
}

\begin{abstract}
Nitrogen $(\mathrm{N})$ and zinc $(\mathrm{Zn})$ are the two major yield-limiting factors of flooded rice cultivation systems. Both nutrients interact and affect availability of the other in alkaline calcareous soils. In order to evaluate the interactive effects of $\mathrm{N}$ and $\mathrm{Zn}$ on yield and quality of Basmati rice, a field study was conducted at Sheikhupura (Site I) and Sargodha (Site II), Pakistan. Nitrogen treatments $(0,40,80,120$ and $160 \mathrm{~kg} / \mathrm{ha}$ ) were kept in main blocks while zinc levels $(0,8,10,12$ and $14 \mathrm{~kg} / \mathrm{ha})$ were kept in sub blocks. The main effects of $\mathrm{N}$ and $\mathrm{Zn}$ levels were significant for grain yield and yield attributes. $\mathrm{N}$ and $\mathrm{Zn}$ interaction significantly improved the grain yield, yield components and all kernel quality parameters, except kernel amylose contents. Combined application of $120 \mathrm{~kg} \mathrm{~N} / \mathrm{ha}$ and $14 \mathrm{~kg} \mathrm{Zn} / \mathrm{ha}$ produced the maximum grain yields at both sites (6.12 and $5.78 \mathrm{t} / \mathrm{ha}$ ). This combination also yielded the maximum kernel lengths and widths, water absorption ratio and kernel protein contents. There was a significant positive correlation between grain yield and total dry matter, panicle-bearing tillers, spikelets panicle, grain weight, and harvest index. Application of $160 \mathrm{~kg} \mathrm{~N} / \mathrm{ha}$ was detrimental to yield and quality attributes and reduced the agronomic efficiency of $\mathrm{N}$ use at both sites. Site comparison showed that soil pH and soil nutrient contents play a significant role in determination of the optimum nitrogen and zinc fertilizer doses for maximum yields.
\end{abstract}

Keywords: agronomic efficiency, aromatic rice, fertilizer, kernel quality, paddy yield

\section{Introduction}

Rice is staple food for more than half of the world's population (Fageria et al., 2008). In Pakistan, rice with an average yield of $2398 \mathrm{~kg} \mathrm{ha}^{-1}$ (Anonymous, 2013) is ranked as the second most essential food of the human diet. Basmati (aromatic) rice is known for its long fluffy grains with minimum kernel dimension, aroma intensity, texture of the cooked rice, high elongation during cooking, palatability and longer shelf life (Ahmad et al., 2005). Most of the Basmati rice in Pakistan is produced in the Punjab province. Both yield potential and quality characteristics of new Basmati varieties such as 'Super Basmati', 'Basmati 2000 ' and 'Shaheen Basmati' has been improved by rigorous breeding efforts. There is a big difference in the yield potential of different rice varieties and the actual yields obtained by the farmers. The yield potential of Basmati varieties ranges from 4.5 to $6 \mathrm{tha} \mathrm{t}^{-1}$ while the farm yields vary between 2.0 to $2.8 \mathrm{t} \mathrm{ha}^{-1}$ (Ahmad et al., 2005; Shivay et al.,
2010). Basmati rice is also an important export commodity of Pakistan. So, quality of Basmati rice is next to rice production. Among major constraints of quality and paddy yields in rice, imbalanced nitrogen fertilization (Wang et al., 2008) and zinc deficiency (Shivay et al., 2010) in soils are the most important variables.

Zinc $(\mathrm{Zn})$ deficiency in staple foods is a major threat in combating malnutrition related health problems in many developing countries (Impa et al., 2013). After nitrogen, zinc is the second most yield-limiting nutrient in rice (Quijano-Guerta et al., 2002). Most of the rice crop in Pakistan is cultivated in alkaline calcareous soils with high clay contents. Due to these soil characteristics, most of the zinc $(\mathrm{Zn})$ applied as fertilizer is adsorbed and only little is recovered by rice crop during the growth period (Tahir $e t$ al., 1992; Rahman et al., 2002). High soil pH is considered to be the most crucial factor in causing $\mathrm{Zn}$ deficiency in Pakistani soils (Qadar, 2002). In addition, $\mathrm{Zn}$ deficiency is also wide spread in these soils (Rashid et al., 1999). Zn 
373

fertilization has also been shown to affect kernel protein contents of rice (Mirzavand, 2007). Since $\mathrm{Zn}$ is a costly fertilizer, its economic use is important from the point of view of poor farmers.

Nitrogen $(\mathrm{N})$ has been an important yield determinant of the flooded rice production systems. High prices, food shortages in developing world and the adverse effects of heavy $\mathrm{N}$ losses from flooded fields however necessitate optimal use of $\mathrm{N}$. Nitrogen losses through ammonia volatilization, leaching and runoff have been recorded from $20-80 \%$ in the rice production (Singh et al., 1998; Griggs et al., 2007; Norman et al., 2009). Economic use of nitrogen fertilizer is especially important for small growers as urea prices are continuously on rise. The response of rice crop to nitrogen fertilizers have been well documented, however the effects of $\mathrm{N}$ interaction with zinc application rates on yield and quality of rice are lacking. Non-judicious use of nitrogen fertilizer could further aggravate $\mathrm{Zn}$ deficiency in alkaline soils and suppress paddy growth and yield (Rashid, 1996). Nitrogen fertilization is found to enhance zinc contents of flooded rice, where urea performed better than $\mathrm{NH}_{4} \mathrm{NO}_{3}$ in increasing $\mathrm{Zn}$ contents (Chaudhry et al., 1977; Singh and Singh, 1981). They observed that higher $\mathrm{Zn}$ contents in plant tissues by nitrogen application were due to better growth, increased $\mathrm{Zn}$ solubility and increased root efficiency for $\mathrm{Zn}$ uptake. Under submerged conditions, urea is more efficient as compared to nitrate containing fertilizers. Urea-N application lowers soil $\mathrm{pH}$ and in addition it forms $\mathrm{NH}_{3}-\mathrm{Zn}$ complex and thus increases $\mathrm{Zn}$ availability under alkaline conditions (Gao et al., 2012). Keeping in view the possible $\mathrm{N} \times \mathrm{Zn}$ interactions in alkaline soils, present study was aimed to identify optimum doses of $\mathrm{N}$ and $\mathrm{Zn}$ for higher grain yields and better quality of Basmati rice.

\section{Materials and methods}

The field experiments were conducted at Adaptive Research Farm Sheikhupura $\left(31.6^{\circ} \mathrm{N}, 74.6^{\circ} \mathrm{E}, 217 \mathrm{~m}\right)$ and Sargodha $\left(32.04^{\circ} \mathrm{N}, 72.67^{\circ} \mathrm{E}, 188 \mathrm{~m}\right)$ during 2009 and 2010. Weather from July to September in 2009 was dry with the rainfall of about $42.1 \%$ below average and in 2010 was wet with rainfall of about $10.5 \%$ above average (Fig. 1). Experiments were laid out in a randomized complete block design with split arrangements and were replicated thrice. Five nitrogen $(\mathrm{N})$ levels $(0,40,80,120$ and $160 \mathrm{~kg} / \mathrm{ha}$ ) were kept in main plots while zinc $(\mathrm{Zn})$ levels $(0,8,10,12$ and $14 \mathrm{~kg} / \mathrm{ha})$ were kept in sub plots. The net plot size was $1.8 \mathrm{~m} \times 12 \mathrm{~m}$. The soil texture at Sheikhupura (site I) was loam (12\% Sand, 70\% Silt and 18\% Clay) with $8.38 \mathrm{pH}, 10.45 \%$ total soluble salts, $0.82 \%$ organic matter, $0.06 \%$ total nitrogen, $10.6 \mathrm{ppm}$ available phosphorus, $216 \mathrm{ppm}$ available potassium and $0.51 \mathrm{mg}$ AB-DPTA extractable $\mathrm{Zn} \mathrm{kg}^{-1}$ soil. While at Sargodha (site II), soil was silt loam (22\% Sand, 59\% Silt and $18 \%$ Clay) with $7.59 \mathrm{pH}$, $10.2 \%$ total soluble salts, $0.94 \%$ organic matter, $0.06 \%$ total nitrogen, $15.9 \mathrm{ppm}$ available phosphorus, $239 \mathrm{ppm}$ available potassium and $0.32 \mathrm{mg}$ AB-DPTA extractable $\mathrm{Zn} \mathrm{kg}^{-1}$ soil.

Rice nursery (cv. 'Super Basmati') was sown during first week of June using hand drill at both sites. Nursery seedlings of 28-30 days old were manually transplanted in puddled fields by keeping a row to row and plant to plant distance of $22.5 \mathrm{~cm}$ on $5^{\text {th }}$ and $7^{\text {th }}$ July of both growing seasons at Sheikhupura and Sargodha, respectively. Before transplantation, half of the total nitrogen and half of the total $\mathrm{Zn}$ (doses as per treatments), 80 $\mathrm{kg} / \mathrm{ha}$ phosphorus and $60 \mathrm{~kg} / \mathrm{ha}$ potassium were applied in the puddle field in the form of urea, $\mathrm{ZnSO}_{4}, \mathrm{SSP}$ and SOP, respectively. The remaining doses of nitrogen and zinc fertilizers were applied during active tillering stage. Butachlor (60\% EC) @800 ml/ha was applied in standing water for weed control (Reddy, 2004). To control borers and leaf folders, Carbofuran (10\% GR)@25 kg/ha was broadcasted at 55 day after transplantation. Irrigation water was maintained at a depth of $3-4 \mathrm{~cm}$ at transplantation and one week afterwards at a depth of $5-6 \mathrm{~cm}$ throughout the growing season till one week before harvesting. An area of $7.5 \mathrm{~m}^{2}$ was harvested from each plot and 20 plants were randomly selected for determination of yield attributes. Final grain and dry matter yields were estimated from $7.5 \mathrm{~m}^{2}$. Manual threshing was done separately for each plot. Agronomic efficiencies of $\mathrm{N}$ and $\mathrm{Zn}$ were calculated as:

$\mathrm{AE}_{\mathrm{N}}=$ grain yield $(\mathrm{kg} / \mathrm{ha})$ with $\mathrm{N}$ application - grain yield (kg/ha) without N application / N application (kg/ha)

$\mathrm{AE}_{\mathrm{Zn}}=$ grain yield $(\mathrm{kg} / \mathrm{ha})$ with $\mathrm{Zn}$ application - grain yield (kg/ha) without $\mathrm{Zn}$ application / $\mathrm{Zn}$ application ( $\mathrm{kg} / \mathrm{ha}$ )

Kernel dimensions (length and width) of 100 normal kernels out of each treatment were measured using a dial caliper and then averaged. Water absorption ratio of kernels was determined by dividing the weight of cooked rice with that of raw rice. Protein contents were calculated by micro-Kjeldahl digestion method to estimate nitrogen content, which was multiplied with factor 5.9 in order to convert into protein (Jacobs, 1958). Kernel amylose contents were determined according to the method of Juliano (1971) by using Spectrophotometer. The data collected were subjected to Fischer's ANOVA using MSTAT-C program. The treatment means were compared using Duncan Multiple Range Test at $5 \%$ probability level.

\section{Results and discussion}

\section{Paddy yield components}

Statistical analysis showed that year effect for different parameters studied in this work at both experimental sites was not significant. Therefore data presented in this work represent the averages of both years (2009 and 2010) for either site. Tillering of Basmati rice was significantly influenced by nitrogen $(\mathrm{N})$ application. Comparison of means (Tab. 1) showed that $\mathrm{N}$ significantly increased the number of paniclebearing tillers up to $120 \mathrm{~kg} \mathrm{~N} / \mathrm{ha}$; thereafter panicle bearing tillers were decreased at a higher dose of N (160 kg/ha). Similar trend was observed at both sites. Promotion of growth and tillering in rice by $\mathrm{N}$ application has been reported by many studies (Mae, 1997; Samonte et al. 2006). Reduction in number of productive tillers at higher $\mathrm{N}$ dose could be the result of excessive vegetative growth (Gebrekidan and Seyoum, 2006). On the other hand, significant effect of $\mathrm{Zn}$ on tiller production was only evident at site I (Sheikhupura) where 12 $\mathrm{kg} \mathrm{Zn} / \mathrm{ha}$ increased the number of panicle bearing tillers in comparison to control (Tab. 1; $0 \mathrm{~kg} \mathrm{Zn/ha).} \mathrm{While} \mathrm{at} \mathrm{site} \mathrm{II}$ (Sargodha), increase in $\mathrm{Zn}$ rates did not significantly affect the number of panicle-bearing tillers. These varying responses to 
Zn supply at two sites of the present experiment could be related to differences in soils characteristics. $\mathrm{Zn}$ nutrition has been shown to have positive influence on tiller production of rice (Impa et al., 2013; Sarwar et al., 2013). The interaction between $\mathrm{N}$ and $\mathrm{Zn}$ regarding panicle-bearing tillers was significant (Tab. 2). Highest number of panicle-bearing tillers hill $^{-1}(13.8$ and 13.1) at sites I and II were produced by $120 \mathrm{~N}+$ $14 \mathrm{Zn}$ and $120 \mathrm{~N}+12 \mathrm{Zn}(\mathrm{kg} / \mathrm{ha})$, respectively.

The number of spikelets panicle ${ }^{-1}$ varied from 88.1 to 110.7 across treatments, sites and years. At both sites, an increase in

Tab. 1. Main effect of nitrogen and zinc rates on yield and yield components of Basmati rice (Oryza sativa L.)

\begin{tabular}{|c|c|c|c|c|c|c|c|c|c|c|c|c|}
\hline \multirow{2}{*}{$\begin{array}{c}\text { Treatments } \\
\mathrm{N} \mathrm{kg} \mathrm{ha}^{-1} / \text { Site }\end{array}$} & \multicolumn{2}{|c|}{$\mathrm{PBT}_{\text {hill }}^{-1}$} & \multicolumn{2}{|c|}{$S$ panicle ${ }^{-1}$} & \multicolumn{2}{|c|}{ 1000- GW (g) } & \multicolumn{2}{|c|}{$\operatorname{TDM}\left(\mathrm{t} \mathrm{ha}^{-1}\right)$} & \multicolumn{2}{|c|}{$\mathrm{GY}\left(\mathrm{t} \mathrm{ha}^{-1}\right)$} & \multicolumn{2}{|c|}{$\mathrm{HI}$} \\
\hline & I & II & I & II & I & II & I & II & I & II & I & II \\
\hline 0 & $9.79^{c}$ & $9.34 \mathrm{c}$ & $101.72 \mathrm{c}$ & $99.33 \mathrm{~d}$ & $19.87 \mathrm{~d}$ & $19.86 \mathrm{e}$ & $9.19 \mathrm{c}$ & $8.81 \mathrm{c}$ & $2.72 \mathrm{c}$ & $2.73 c$ & $29.41 \mathrm{~d}$ & $30.77 \mathrm{e}$ \\
\hline 40 & $10.47 \mathrm{c}$ & $10.03 c$ & $107.65 b$ & $105.43 c$ & $20.44 c$ & $20.53 \mathrm{~d}$ & $9.79 \mathrm{c}$ & $10.01 \mathrm{c}$ & $3.00 \mathrm{c}$ & $3.29 \mathrm{c}$ & $30.64 d$ & $32.63 \mathrm{~d}$ \\
\hline 80 & $11.37 \mathrm{~b}$ & $10.60 \mathrm{bc}$ & $108.30 \mathrm{~b}$ & $106.90 \mathrm{~b}$ & $21.27 \mathrm{~b}$ & $21.32 \mathrm{c}$ & $11.73 b$ & $11.58 \mathrm{~b}$ & $3.95 b$ & $4.05 \mathrm{~b}$ & $33.42 \mathrm{c}$ & $34.68 \mathrm{c}$ \\
\hline 120 & $13.08 \mathrm{a}$ & $12.06 \mathrm{a}$ & $110.07 \mathrm{a}$ & $108.06 \mathrm{a}$ & $23.02 \mathrm{a}$ & $22.67 a$ & $15.07 \mathrm{a}$ & $14.03 \mathrm{a}$ & $5.57 \mathrm{a}$ & $5.40 \mathrm{a}$ & $36.94 a$ & $38.48 \mathrm{a}$ \\
\hline 160 & $11.74 \mathrm{~b}$ & $11.34 \mathrm{ab}$ & $108.65 b$ & $106.23 \mathrm{bc}$ & $21.65 b$ & $22.04 \mathrm{~b}$ & $12.62 \mathrm{~b}$ & $13.71 \mathrm{a}$ & $4.46 \mathrm{~b}$ & $4.99 a$ & $35.18 \mathrm{~b}$ & $36.44 b$ \\
\hline $\operatorname{LSD}(\mathrm{P} \leq 0.05)$ & 0.88 & 0.95 & 1.03 & 0.87 & 0.42 & 0.37 & 1.21 & 1.43 & 0.77 & 0.69 & 1.18 & 1.47 \\
\hline \multicolumn{13}{|l|}{$\mathrm{Zn} \mathrm{kg} \mathrm{ha}^{-1} /$ Site } \\
\hline 0 & $10.53 b$ & 10.50 & $104.78 \mathrm{c}$ & $102.75 c$ & $20.54 \mathrm{~d}$ & $20.73 c$ & $10.68 \mathrm{c}$ & $10.82 \mathrm{c}$ & $3.48 \mathrm{~d}$ & $3.72 \mathrm{~d}$ & $31.73 c$ & $33.52 \mathrm{~d}$ \\
\hline 8 & $11.18 \mathrm{ab}$ & 10.51 & $107.50 \mathrm{~b}$ & $105.25 b$ & $21.24 \mathrm{c}$ & $21.24 \mathrm{~b}$ & $11.53 \mathrm{~b}$ & $11.41 \mathrm{bc}$ & $3.88 \mathrm{c}$ & $3.99 \mathrm{c}$ & $33.25 b$ & $34.46 c$ \\
\hline 10 & $11.48 \mathrm{ab}$ & 10.73 & $107.77 \mathrm{ab}$ & $106.16 \mathrm{a}$ & $21.53 \mathrm{a}$ & $21.46 \mathrm{a}$ & $11.83 \mathrm{ab}$ & $11.75 \mathrm{ab}$ & $3.97 \mathrm{bc}$ & $4.10 b c$ & $33.14 b$ & $34.38 \mathrm{c}$ \\
\hline 12 & $11.73 \mathrm{a}$ & 11.07 & $108.21 \mathrm{a}$ & $106.04 a$ & $21.40 \mathrm{~b}$ & $21.47 \mathrm{a}$ & $12.12 \mathrm{ab}$ & $12.03 \mathrm{ab}$ & $4.10 \mathrm{ab}$ & $4.27 \mathrm{ab}$ & $33.23 \mathrm{~b}$ & $34.96 \mathrm{~b}$ \\
\hline 14 & $11.52 \mathrm{ab}$ & 10.86 & $108.13 a$ & $\begin{array}{c}105.76 a \\
b\end{array}$ & $21.54 \mathrm{a}$ & $21.53 \mathrm{a}$ & $12.25 \mathrm{a}$ & $12.13 \mathrm{a}$ & $4.26 \mathrm{a}$ & $4.40 \mathrm{a}$ & $34.12 \mathrm{a}$ & $35.69 \mathrm{a}$ \\
\hline $\operatorname{LSD}(\mathrm{P} \leq 0.05)$ & 1.09 & NS & 0.58 & 0.52 & 0.12 & 0.15 & 0.71 & 0.65 & 0.21 & 0.18 & 0.57 & 0.44 \\
\hline
\end{tabular}

$\mathrm{N}=$ nitrogen; $\mathrm{Zn}=$ zinc; TDM = total dry matter; GY = grain yield; PBT = panicle-bearing, tillers; $\mathrm{S}=$ spikelets; $\mathrm{GW}$ = grain weight; $\mathrm{HI}=$ harvest index; $\mathrm{NS}=\mathrm{Not}$ Significant.

Treatment means were separated with Duncan Multiple Range Test at $5 \%$ probability. Different letters on treatment means within each column show statistical differences at $P \leq 0.05$.

Tab. 2. Interactive effect of nitrogen and zinc rates on yield components of Basmati rice (Oryza sativa L.)

\begin{tabular}{|c|c|c|c|c|c|c|c|}
\hline \multicolumn{2}{|c|}{ Treatments } & \multicolumn{2}{|c|}{ PBT hill $^{-1}$} & \multicolumn{2}{|c|}{$S$ panicle ${ }^{-1}$} & \multicolumn{2}{|c|}{ 1000-GW } \\
\hline $\mathrm{N}\left(\mathrm{kg} \mathrm{ha}^{-1}\right)$ & $\mathrm{Zn}\left(\mathrm{kg} \mathrm{ha}^{-1}\right)$ & Site I & Site II & Site I & Site II & Site I & Site II \\
\hline 0 & 0 & 7.8 & 7.7 & 90.2 & 88.1 & 18.1 & 18.2 \\
\hline 0 & 8 & 9.9 & 9.5 & 103.1 & 99.4 & 20.2 & 20.0 \\
\hline 0 & 10 & 10.3 & 9.7 & 104.9 & 103.7 & 21.1 & 20.8 \\
\hline 0 & 12 & 11.4 & 10.4 & 106.0 & 103.3 & 20.1 & 20.3 \\
\hline 0 & 14 & 9.4 & 9.4 & 104.5 & 101.6 & 20.0 & 20.1 \\
\hline 40 & 0 & 10.5 & 10.1 & 108.8 & 105.8 & 20.3 & 20.2 \\
\hline 40 & 8 & 10.4 & 9.8 & 107.9 & 105.5 & 20.6 & 20.5 \\
\hline 40 & 10 & 10.6 & 10.1 & 106.5 & 105.3 & 20.3 & 20.3 \\
\hline 40 & 12 & 10.3 & 9.8 & 107.1 & 105.3 & 20.5 & 20.8 \\
\hline 40 & 14 & 10.6 & 10.3 & 108.0 & 105.3 & 20.4 & 20.9 \\
\hline 80 & 0 & 10.4 & 10.1 & 107.3 & 105.6 & 20.5 & 21.0 \\
\hline 80 & 8 & 11.3 & 10.4 & 108.2 & 107.4 & 21.2 & 21.3 \\
\hline 80 & 10 & 11.4 & 10.7 & 108.4 & 107.1 & 21.3 & 21.2 \\
\hline 80 & 12 & 11.8 & 10.8 & 108.7 & 107.1 & 21.5 & 21.5 \\
\hline 80 & 14 & 12.1 & 11.0 & 108.8 & 107.3 & 21.9 & 21.7 \\
\hline 120 & 0 & 12.5 & 11.4 & 109.4 & 107.9 & 22.5 & 22.3 \\
\hline 120 & 8 & 12.7 & 11.7 & 109.8 & 107.6 & 22.7 & 22.4 \\
\hline 120 & 10 & 13.1 & 11.8 & 110.1 & 108.2 & 23.1 & 22.8 \\
\hline 120 & 12 & 13.3 & 13.1 & 110.3 & 108.0 & 23.1 & 22.9 \\
\hline 120 & 14 & 13.8 & 12.4 & 110.7 & 108.6 & 23.6 & 23.0 \\
\hline 160 & 0 & 11.4 & 11.7 & 108.3 & 105.8 & 21.5 & 21.9 \\
\hline 160 & 8 & 11.7 & 11.2 & 108.5 & 106.3 & 21.5 & 22.0 \\
\hline 160 & 10 & 12.0 & 11.3 & 108.9 & 106.5 & 21.9 & 22.2 \\
\hline 160 & 12 & 11.8 & 11.3 & 108.9 & 106.4 & 21.8 & 22.1 \\
\hline 160 & 14 & 11.8 & 11.3 & 108.6 & 106.1 & 21.8 & 22.0 \\
\hline \multicolumn{2}{|c|}{$\operatorname{LSD}(\mathrm{P} \leq 0.05)$} & 1.21 & 1.45 & 1.14 & 1.04 & 0.54 & 0.49 \\
\hline \multicolumn{2}{|c|}{ F-Significant } & $* *$ & ${ }^{* *}$ & ${ }^{* *}$ & ${ }^{* *}$ & ${ }^{*}$ & ${ }^{*}$ \\
\hline
\end{tabular}

$\mathrm{N}=$ nitrogen; $\mathrm{Zn}=$ zinc; PBT = panicle-bearing tillers; $\mathrm{S}=$ spikelets; $\mathrm{GW}=$ grain weight; $\mathrm{NS}=$ not significant; ${ }^{*},{ }^{* *}$ : Significant at 0.05 and 0.01, respectively 
375

the rate of $\mathrm{N}$ application up to $120 \mathrm{~kg} \mathrm{ha}^{-1}$ progressively increased the number of spikelets panicle $\mathrm{ever}^{-\mathrm{c}}$ control (Tab. 1). Gebrekidan and Seyoum (2006) revealed that increase in spikelet number by $\mathrm{N}$ is the result of increase in panicle length. In a recent study Ding et al. (2014) showed that the increase in the number of spikelets panicle ${ }^{-1}$ by nitrogen fertilization is associated with an increase in cytokinen contents. Whereas at $160 \mathrm{~kg} \mathrm{~N} / \mathrm{ha}$, the decrease in spikelets panicle ${ }^{-1}$ as compared to that of $120 \mathrm{~kg} \mathrm{~N} / \mathrm{ha}$ (Tab. 1) may be because of increased competition among tillers for carbohydrate supply (Wu et al., 1998). Different $\mathrm{Zn}$ application rates also significantly affected the number of spikelets panicle ${ }^{-1}$ at both sites. Though spikelets panicle $^{-1}$ at $\mathrm{Zn}$ rates of $12-14 \mathrm{~kg} / \mathrm{ha}$ were significantly higher over control, the gain at higher $\mathrm{Zn}$ doses was relatively small at both sites (Tab. 1). Zinc deficiency affects floral development of plants by lowering enzyme activity (Pandey $e t$ al., 2001). Improvement in different grain yield components with an increase in $\mathrm{Zn}$ levels could be attributed to adequate $\mathrm{Zn}$ supply that might have affected the metabolic and enzymatic activity (Hafeez et al., 2010). Combined effect of $\mathrm{N}$ and $\mathrm{Zn}$ on spikelets panicle $^{-1}$ was also significant. Maximum number of spikelets panicle ${ }^{-1}$ at both sites were recorded where $120 \mathrm{~N}+14$ $\mathrm{Zn}$ (kg/ha) were applied (Tab. 2). While control plots (where $\mathrm{N}$ and $\mathrm{Zn}$ were not applied) showed the lowest number of spikelets panicle ${ }^{-1}$.

Grain weight of rice kernels is an important yield attribute, which is mostly determined by genetic potential rather than environmental conditions (Ashraf et al., 1999). Data showed that thousand grain weight significantly increased with an increase in $\mathrm{N}$ fertilizer up till $120 \mathrm{~kg} / \mathrm{ha}$, then declined at 160 $\mathrm{kg} \mathrm{N} / \mathrm{ha}$ (Tab. 1). Similar response was evident at both sites. Plots not supplied with $\mathrm{N}$ showed the lowest grain weights. Limited availability of nitrogen during grain filling stages affects carbohydrates supply to developing seeds and therefore decreases grain weight (Mae, 1997). Mean comparisons showed that Zinc application significantly increased the grain weight. At site I (Sheikhupura) increment in Zn fertilizer progressively increased the thousand grain weight, whereas at site II (Sargodha) grain weight was significantly increased till 10 $\mathrm{kg} \mathrm{Zn/ha}$ and then remained static onwards (Tab. 1). Combined application of $\mathrm{N}$ and $\mathrm{Zn}$ also had a significant positive effect on thousand grain weight at both sites. Highest thousand grain weight was found where $120 \mathrm{~N}+14 \mathrm{Zn}$ (kg/ha) was applied (Tab.2).

\section{Total dry matter, paddy yield and harvest index}

The nitrogen fertilizer significantly increased the total dry matter (TDM) yield with increasing rate of $\mathrm{N}$ application at both sites up to $120 \mathrm{~kg} \mathrm{ha}^{-1}$, thereafter TDM was slightly decreased at $160 \mathrm{~kg} \mathrm{ha}^{-1}$ and difference between the two treatments were significant only at Sheikhupura site (Tab. 1). Increase in dry matter yield by $\mathrm{N}$ application is apparently the result of growth promotion by nitrogen. Similarly, increasing rates of $\mathrm{Zn}$ application significantly increased TDM up to 10 $\mathrm{kg} \mathrm{ha}^{-1}$ at both sites (Tab. 1). Increment in Zn application from $10 \mathrm{~kg} \mathrm{Zn} / \mathrm{ha}$ onwards did not significantly affect the TDM yield. Wissuwa et al. (2006) observed that $Z$ n deficiency caused stunted growth and reduced the TDM yield of many rice cultivars. They further exhibited that lower TDM yields under Zn deficiency are well correlated with lower $Z n$ contents in rice plants. Interaction between $\mathrm{N}$ and $\mathrm{Zn}$ application rate affecting
TDM yield was significant at both sites (Tab. 3). The maximum TDM yields $16.34 \mathrm{t} \mathrm{ha}^{-1}$ and $14.79 \mathrm{t} \mathrm{ha}^{-1}$ at Sheikhupura and Sargodha sites, respectively, were recorded where $120 \mathrm{~N}+14 \mathrm{Zn}(\mathrm{kg} / \mathrm{ha})$ was applied.

Grain/paddy yields varied between 1.93-6.12 t/ha across sites, years and fertilizer treatments. Nitrogen application significantly increased the rice grain yield with each increment up to $120 \mathrm{~kg} \mathrm{~N} / \mathrm{ha}$ at both sites (Tab. 1). The increase in grain yield with increasing $\mathrm{N}$ rates could be ascribed to more productive tillers and a higher grain weight. Grain yield had a significant positive correlation with total dry matter, paniclebearing tillers, spikelets panicle $e^{-1}$, grain weight, and harvest index at both sites (Tab. 4). The variances for six traits (total dry matter, grain yield, panicle-bearing tillers, spikelets panicle ${ }^{-1}$, grain weight, and harvest index) were homogenous across 2009 and 2010; thus data for both years at each site were combined for correlation analysis. Comparable paddy yields $\left(5.34 \mathrm{t} \mathrm{ha}^{-1}\right)$ for rice cultivar Basmati 2000 have been achieved at $175 \mathrm{~kg} \mathrm{~N}$ $\mathrm{ha}^{-1}$ (Manzoor et al., 2006). They showed that increases in paddy yields at higher $\mathrm{N}$ supply were well correlated with an increase in number of grains panicle ${ }^{-1}$ and 1000-grain weight. Highest $\mathrm{N}$ dose (160 kg N/ha) in the experiment significantly reduced the grain yield when compared with $120 \mathrm{~kg} \mathrm{~N} / \mathrm{ha}$ at site I (Tab. 1). However, the differences in grain yield between 120 and $160 \mathrm{~kg} \mathrm{~N} / \mathrm{ha}$ at site II were statistically at par. Reduction in grain yield at relatively higher $\mathrm{N}$ application might be the result of excessive vegetative growth and poor carbohydrate supply to developing grains. Nitrogen supply in excess is also known to increase the incidence of lodging and poor grain filling in rice (Saito, 1991).

Mean comparisons for $\mathrm{Zn}$ application showed that grain yield was significantly increased with each increment in $\mathrm{Zn}$ fertilizer. The highest grain yields 4.26 and $4.40 \mathrm{t} / \mathrm{ha}$ were recorded at site I and II, respectively, where $14 \mathrm{~kg} \mathrm{Zn} / \mathrm{ha}$ was applied (Tab. 1). The gain in grain yields at higher $\mathrm{Zn}$ levels could probably be the result of enhanced $\mathrm{Zn}$ concentration in the plant parts especially in rice grains (Rashid et al., 2002). Interactive effects of $\mathrm{N}$ and $\mathrm{Zn}$ application on grain yield at both sites were also significant. Application of $120 \mathrm{~N}+14 \mathrm{Zn}$ $(\mathrm{kg} / \mathrm{ha})$ produced the maximum grain yields of 6.12 and 5.78 t/ha at site I (Sheikhupura) and Site II (Sargodha), respectively (Tab. 3). The lowest grain yields were obtained where nitrogen and zinc fertilizers were not applied. Higher paddy grain yields at treatments $120 \mathrm{~N}+14 \mathrm{Zn}(\mathrm{kg} / \mathrm{ha}$ ) could be associated to higher tillering, more number of spikelets panicle ${ }^{-1}$, higher grain weight as compared to unfertilized plots or plots where less amount of $\mathrm{N}$ and $\mathrm{Zn}$ were applied (Tab. 4).

Increasing rates of $\mathrm{N}$ application significantly increased harvest index (HI) up to $120 \mathrm{~kg} \mathrm{~N} / \mathrm{ha}$, thereafter HI significantly decreased at higher rate of $\mathrm{N}$ application $160 \mathrm{~kg}$ $\mathrm{N} /$ ha at both sites (Tab. 1). Reduction in $\mathrm{HI}$ at higher $\mathrm{N}$ dose is possibly the result of more carbohydrates supply towards dry matter accumulation than grain filling (Gebrekidan and Seyoum, 2006). Data also showed that $\mathrm{Zn}$ application at the rate of $14 \mathrm{~kg} / \mathrm{ha}$ significantly increased HI compared to other $\mathrm{Zn}$ treatments at both the sites (Tab. 1). Statistical differences in $\mathrm{HI}$ between 8, 10 and $12 \mathrm{~kg} \mathrm{Zn} /$ ha were however not significant at Sheikhupura site. A significant interaction between $\mathrm{N}$ x $\mathrm{Zn}$ showed that $120 \mathrm{~N}+12 \mathrm{Zn}$ (kg/ha) combination gave the maximum $\mathrm{HI}(37.5,39.24)$ at Sheikhupura and Sargodha, respectively, whereas the minimum HI values 25.8 and 27.2 were observed at either site 
when $\mathrm{N}$ and $\mathrm{Zn}$ were not applied (Tab. 3). Site comparison solubility and thus produced better grain yields. Khan et al. showed that grain yields and HI at all $\mathrm{Zn}$ levels were slightly higher at Sargodha (Site II) than that of Sheikhupura (Site I) despite relatively lower soil $\mathrm{Zn}$ contents at the former site. Lower relative soil $\mathrm{pH}$ at Site II might have increased $\mathrm{Zn}$ (2007) compared the response of paddy yields to $\mathrm{Zn}$ fertilizer applied under different soil conditions. They noticed that the soils having low $\mathrm{pH}$ and lower $\mathrm{CaCO}_{3}$ contents gave the highest yield response to $\mathrm{Zn}$.

Tab. 3. Interactive effect of nitrogen and zinc rates on total dry matter, grain yield and harvest index of Basmati rice (Oryza sativa L.)

\begin{tabular}{|c|c|c|c|c|c|c|c|}
\hline \multicolumn{2}{|c|}{ Treatments } & \multicolumn{2}{|c|}{$\operatorname{TDM}\left(\mathrm{t} \mathrm{ha} \mathrm{a}^{-1}\right)$} & \multicolumn{2}{|c|}{ GY $\left(t h^{-1}\right)$} & \multicolumn{2}{|c|}{ HI } \\
\hline $\mathrm{N}\left(\mathrm{kg} \mathrm{ha}^{-1}\right.$ & $\mathrm{Zn}\left(\mathrm{kg} \mathrm{ha}^{-1}\right)$ & Site I & Site II & Site I & Site II & Site I & Site II \\
\hline 0 & 0 & 7.5 & 7.3 & 1.93 & 2.00 & 25.8 & 27.2 \\
\hline 0 & 8 & 9.3 & 8.6 & 2.88 & 2.75 & 30.9 & 31.7 \\
\hline 0 & 10 & 9.8 & 9.1 & 3.08 & 2.89 & 31.5 & 31.6 \\
\hline 0 & 12 & 10.2 & 9.6 & 2.93 & 3.00 & 28.7 & 31.1 \\
\hline 0 & 14 & 9.3 & 9.3 & 2.80 & 3.03 & 30.2 & 32.3 \\
\hline 40 & 0 & 10.1 & 10.0 & 3.21 & 3.37 & 31.8 & 33.6 \\
\hline 40 & 8 & 9.7 & 10.0 & 2.92 & 3.24 & 30.3 & 32.4 \\
\hline 40 & 10 & 9.8 & 10.1 & 2.89 & 3.24 & 29.6 & 32.0 \\
\hline 40 & 12 & 9.6 & 9.9 & 2.92 & 3.25 & 30.3 & 32.5 \\
\hline 40 & 14 & 9.9 & 10.1 & 3.04 & 3.32 & 30.6 & 32.7 \\
\hline 80 & 0 & 9.8 & 10.4 & 2.90 & 3.38 & 29.6 & 32.4 \\
\hline 80 & 8 & 11.7 & 11.1 & 3.88 & 3.70 & 33.3 & 33.3 \\
\hline 80 & 10 & 11.7 & 11.5 & 3.90 & 3.86 & 33.4 & 33.6 \\
\hline 80 & 12 & 12.4 & 12.2 & 4.29 & 4.41 & 34.5 & 36.1 \\
\hline 80 & 14 & 13.1 & 12.8 & 4.76 & 4.88 & 36.3 & 38.1 \\
\hline 120 & 0 & 13.9 & 13.1 & 5.04 & 4.95 & 36.3 & 37.9 \\
\hline 120 & 8 & 14.4 & 13.8 & 5.33 & 5.25 & 37.0 & 38.1 \\
\hline 120 & 10 & 15.1 & 14.1 & 5.50 & 5.39 & 36.4 & 38.1 \\
\hline 120 & 12 & 15.6 & 14.4 & 5.86 & 5.64 & 37.5 & 39.2 \\
\hline 120 & 14 & 16.3 & 14.8 & 6.12 & 5.78 & 37.5 & 39.1 \\
\hline 160 & 0 & 12.2 & 13.3 & 4.32 & 4.87 & 35.1 & 36.6 \\
\hline 160 & 8 & 12.6 & 13.6 & 4.41 & 5.00 & 34.8 & 36.8 \\
\hline 160 & 10 & 12.9 & 14.0 & 4.48 & 5.11 & 34.8 & 36.6 \\
\hline 160 & 12 & 12.8 & 14.0 & 4.50 & 5.03 & 35.2 & 35.9 \\
\hline 160 & 14 & 12.6 & 13.7 & 4.58 & 4.98 & 36.1 & 36.4 \\
\hline \multicolumn{2}{|c|}{$\operatorname{LSD}(\mathrm{P} \leq 0.05)$} & 1.30 & 1.27 & 0.91 & 0.85 & 3.13 & 2.88 \\
\hline \multicolumn{2}{|c|}{ F-Significant } & ${ }^{* *}$ & ${ }^{* *}$ & ${ }^{* *}$ & ${ }^{* *}$ & ${ }^{* *}$ & ${ }^{* *}$ \\
\hline
\end{tabular}

\section{Agronomic efficiency}

Agronomic efficiency of nitrogen use $\left(\mathrm{AE}_{\mathrm{N}}\right)$ or zinc use $\left(\mathrm{AE}_{\mathrm{Zn}}\right)$ describes the capability of yield increase per kg nitrogen or zinc applied, respectively. Agronomic nutrient use efficiency depends on various factors such as nutrient availability, soil conditions, fertilizer source and dose, and most importantly crop acquisition efficiency (Mengel and Kirkby, 2001). Nitrogen application increased $\mathrm{AE}_{\mathrm{N}}$ up to $120 \mathrm{~kg} \mathrm{~N} / \mathrm{ha}$, thereafter further increase in nitrogen rate $(160 \mathrm{~kg} \mathrm{~N} / \mathrm{ha})$ reduced $\mathrm{AE}_{\mathrm{N}}$ at both sites (Fig. 2). The minimum $\mathrm{AE}_{\mathrm{N}} 7.0$ and $14.1 \mathrm{~kg}$ grain $/ \mathrm{kg} \mathrm{N}$ were obtained with the application of 40 $\mathrm{kg} \mathrm{N} / \mathrm{ha}$ whereas the maximum $\mathrm{AE}_{\mathrm{N}} 23.8$ and $22.3 \mathrm{~kg}$ grain/ $\mathrm{kg} \mathrm{N}$ were recorded at application of $120 \mathrm{~kg} \mathrm{~N} / \mathrm{ha}$ at site I and site II, respectively (Fig. 2). Agronomic efficiencies for $\mathrm{N}$ use (AEN) for irrigated rice varied between $11.5 \mathrm{~kg}$ grain $/ \mathrm{kg} \mathrm{N}$ in on-farm studies (Dobermann et al., 2002) to $21.6 \mathrm{~kg}$ grain $/ \mathrm{kg}$

Tab. 4. Correlation between yield and yield components of Basmati rice (Oryza sativa L.)

\begin{tabular}{clll}
\hline Correlated Traits & $\begin{array}{c}\text { Site I } \\
(\mathrm{n}=12)\end{array}$ & $\begin{array}{c}\text { Site II } \\
(\mathrm{n}=12)\end{array}$ & $\begin{array}{c}\text { Pooled } \\
(\mathrm{n}=24)\end{array}$ \\
\hline GY vs. TDM & $0.999^{* *}$ & $0.996^{* *}$ & $0.989^{* *}$ \\
GY vs. PBT hill-1 & $0.981^{* *}$ & $0.728^{* *}$ & $0.747^{* *}$ \\
GY vs. S Panicle-1 & $0.788^{* *}$ & $0.802^{* *}$ & $0.663^{* *}$ \\
GY vs. 1000-GW & $0.986^{* *}$ & $0.944^{* *}$ & $0.961^{* *}$ \\
GY vs. HI & $0.705^{*}$ & $0.990^{* *}$ & $0.840^{* *}$ \\
\hline TDM = total dry matter; GY = grain yield; PBT $=$ panicle-bearing tillers; S $=$ \\
spikelets; GW = grain weight; HI = harvest index; ${ }^{* * *}$ : Significant at 0.05 and \\
0.01, respectively.
\end{tabular}
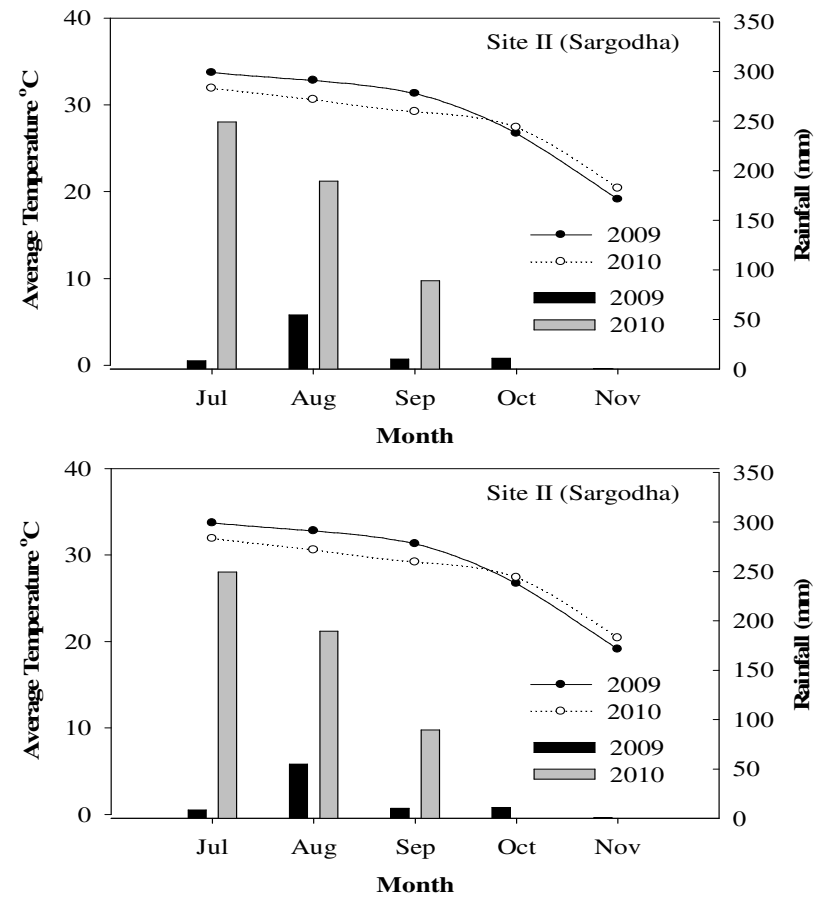

Fig. 1. Meteorological data for growing seasons during 2009-2010 at two cultivation sites 
377

$\mathrm{N}$ in research trials (Ladha et al., 2005) due to greater variability in soil and climatic conditions and incidence of insect/pest attack at farmer's field. Conversely, increase in $\mathrm{Zn}$ rates reduced the agronomic efficiency of $\mathrm{Zn}$ use $\left(\mathrm{AE}_{\mathrm{Zn}}\right)$ at both sites.
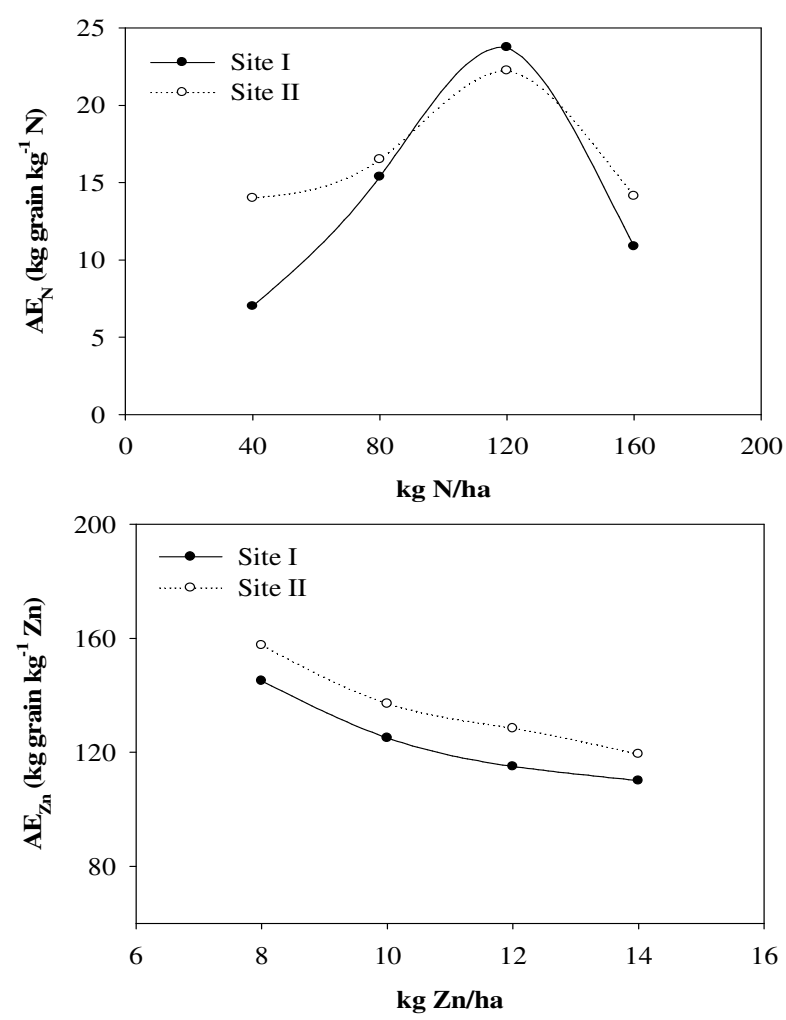

Fig. 2. Agronomic efficiency of Basmati rice (Oryza sativa L.) for nitrogen $\left(\mathrm{AE}_{\mathrm{N}}\right)$ and zinc $\left(\mathrm{AE}_{\mathrm{Zn}}\right)$ utilization at experimental site I (Sheikhupura) and II (Sargodha)
Highest $\mathrm{AE}_{\mathrm{Zn}}$ were recorded at lower $\mathrm{Zn}$ doses at both sites (Fig. 2). High $\mathrm{Zn}$ use efficiency and high agronomic $\mathrm{Zn}$ efficiency at lower $\mathrm{Zn}$ doses have also been reported for barley (Genc et al., 2002) and rice (Muthukumararaj and Sriramachandrasekharan, 2012), respectively. Comparison of both sites showed that $\mathrm{AE}_{\mathrm{Zn}}$ values were higher at site II (Sargodha) than site I (Sheikhupura) under all Zn treatments. This varied response could probably be due to differences in inherent soil zinc contents at both sites. It seems that lower $\mathrm{Zn}$ contents $(0.32 \mathrm{mg} \mathrm{Zn/} \mathrm{kg}$ soil) at site II as compared to site I ( $0.51 \mathrm{mg} \mathrm{Zn} / \mathrm{kg}$ soil) caused the relatively better yield response to applied $\mathrm{Zn}$ at site II.

\section{Kernel quality}

Combined application of $\mathrm{N}$ and $\mathrm{Zn}$ significantly improved the kernel dimensions (kernel length and width) at both sites (Tab. 5). Nitrogen application significantly increased the kernel length at each increment up to $120 \mathrm{~kg} \mathrm{~N} /$ ha where significant $\mathrm{Zn}$ response on kernel length was only evident at the highest dose of the experiment $(14 \mathrm{~kg} \mathrm{Zn} / \mathrm{ha})$. Application of $120 \mathrm{~N}+$ $14 \mathrm{Zn}(\mathrm{kg} / \mathrm{ha})$ produced the highest kernel lengths $7.04 \mathrm{~mm}$ and $6.31 \mathrm{~mm}$ at site I and II, respectively (Tab. 5). On the other hand, increase in both $\mathrm{N}$ and $\mathrm{Zn}$ progressively increased the kernel widths at both sites. Kernel width varied between 1.07 to $2.99 \mathrm{~mm}$ across years, $\mathrm{N}$ and $\mathrm{Zn}$ treatments and sites with maximum values obtained at $120 \mathrm{~N}+14 \mathrm{Zn}(\mathrm{kg} / \mathrm{ha})$ and minimum values at $0 \mathrm{~N}+0 \mathrm{Zn}(\mathrm{kg} / \mathrm{ha})$. An improvement in kernel dimensions (kernel length and kernel width) by increased $\mathrm{N}$ fertilization has also been shown by Maqsood et al. (2013). Both Khan et al. (2009) and Shivay et al. (2005) reported that Zn application @ 10-15 kg/ha improved the yield and quality of Basmati rice in Pakistan and India. Water absorption ratio and protein contents of kernels were also significantly improved by combined application of $\mathrm{N}$ and $\mathrm{Zn}$ at both sites.

Tab. 5. Interactive effect of nitrogen and zinc rates on kernel quality of Basmati rice (Oryza sativa L.)

\begin{tabular}{|c|c|c|c|c|c|c|c|c|c|c|c|}
\hline \multicolumn{2}{|c|}{ Treatments } & \multicolumn{2}{|c|}{$\mathrm{KL}(\mathrm{mm})$} & \multicolumn{2}{|c|}{$\mathrm{KW}(\mathrm{mm})$} & \multicolumn{2}{|c|}{ WAR } & \multicolumn{2}{|c|}{$\mathrm{PC}(\%)$} & \multicolumn{2}{|c|}{$\mathrm{AC}(\%)$} \\
\hline $\mathrm{N}\left(\mathrm{kg} \mathrm{ha}^{-1}\right)$ & $\mathrm{Zn}\left(\mathrm{kgha}^{-1}\right)$ & Site I & Site II & Site I & Site II & Site I & Site II & Site I & Site II & Site I & Site II \\
\hline 0 & 0 & 4.95 & 4.60 & 1.07 & 1.36 & 3.85 & 3.66 & 5.54 & 8.36 & 21.0 & 19.9 \\
\hline 0 & 8 & 5.05 & 4.67 & 1.17 & 1.41 & 4.09 & 3.76 & 5.97 & 8.49 & 21.4 & 20.0 \\
\hline 0 & 10 & 5.22 & 4.76 & 1.21 & 1.34 & 4.18 & 3.79 & 6.54 & 8.66 & 22.1 & 20.0 \\
\hline 0 & 12 & 5.18 & 4.86 & 1.21 & 1.35 & 4.14 & 3.79 & 6.22 & 8.83 & 21.7 & 20.1 \\
\hline 0 & 14 & 5.14 & 4.91 & 1.21 & 1.44 & 4.06 & 3.85 & 6.03 & 8.93 & 21.6 & 20.3 \\
\hline 40 & 0 & 5.22 & 5.04 & 1.21 & 1.36 & 4.18 & 4.07 & 6.28 & 9.16 & 22.1 & 20.4 \\
\hline 40 & 8 & 5.26 & 5.14 & 1.23 & 1.35 & 4.18 & 3.94 & 6.31 & 9.35 & 22.1 & 20.6 \\
\hline 40 & 10 & 5.19 & 5.20 & 1.19 & 1.41 & 4.12 & 4.00 & 6.17 & 9.45 & 21.9 & 20.6 \\
\hline 40 & 12 & 5.17 & 5.14 & 1.21 & 1.43 & 4.12 & 4.04 & 6.19 & 9.35 & 22.0 & 20.8 \\
\hline 40 & 14 & 5.21 & 5.20 & 1.23 & 1.44 & 4.14 & 4.08 & 6.23 & 9.45 & 22.0 & 21.0 \\
\hline 80 & 0 & 5.22 & 5.34 & 1.21 & 1.50 & 4.15 & 4.71 & 6.24 & 9.71 & 21.9 & 21.1 \\
\hline 80 & 8 & 5.65 & 5.41 & 1.71 & 1.62 & 5.12 & 4.97 & 7.19 & 9.84 & 22.7 & 21.2 \\
\hline 80 & 10 & 5.73 & 5.54 & 1.73 & 1.63 & 5.11 & 4.86 & 7.20 & 10.07 & 22.9 & 21.5 \\
\hline 80 & 12 & 5.99 & 5.61 & 1.90 & 1.75 & 5.42 & 4.87 & 7.50 & 10.19 & 23.0 & 21.6 \\
\hline 80 & 14 & 6.13 & 5.75 & 2.09 & 1.92 & 5.70 & 5.28 & 7.78 & 10.46 & 22.9 & 21.7 \\
\hline 120 & 0 & 6.37 & 5.70 & 2.30 & 1.95 & 6.17 & 5.20 & 8.25 & 10.37 & 23.1 & 22.0 \\
\hline 120 & 8 & 6.49 & 5.81 & 2.47 & 2.07 & 6.38 & 5.36 & 8.46 & 10.57 & 23.1 & 22.0 \\
\hline 120 & 10 & 6.63 & 5.98 & 2.68 & 2.26 & 6.73 & 5.68 & 8.81 & 10.87 & 22.9 & 22.1 \\
\hline 120 & 12 & 6.79 & 6.09 & 2.54 & 2.26 & 7.12 & 5.61 & 9.20 & 11.08 & 23.2 & 22.1 \\
\hline 120 & 14 & 7.04 & 6.31 & 2.99 & 2.27 & 7.40 & 5.65 & 9.14 & 11.47 & 23.3 & 22.2 \\
\hline 160 & 0 & 5.69 & 5.94 & 1.79 & 2.21 & 5.02 & 5.11 & 7.10 & 10.80 & 22.8 & 21.9 \\
\hline 160 & 8 & 5.95 & 6.26 & 1.93 & 2.06 & 5.31 & 4.85 & 7.40 & 11.39 & 22.9 & 21.9 \\
\hline 160 & 10 & 6.07 & 6.12 & 2.10 & 2.11 & 5.65 & 5.00 & 7.73 & 11.13 & 23.1 & 21.8 \\
\hline 160 & 12 & 6.01 & 6.23 & 2.05 & 1.99 & 5.36 & 4.87 & 7.44 & 11.32 & 23.0 & 21.9 \\
\hline 160 & 14 & 5.90 & 6.18 & 1.96 & 2.12 & 5.42 & 4.99 & 7.51 & 11.24 & 22.9 & 21.9 \\
\hline \multicolumn{2}{|c|}{$\operatorname{LSD}(\mathrm{P} \leq 0.05)$} & 0.56 & 0.49 & 0.31 & 0.26 & 0.69 & 0.57 & 1.19 & 1.16 & 2.41 & 2.38 \\
\hline \multicolumn{2}{|c|}{ F-Significant } & ${ }^{*}$ & ${ }^{*}$ & ${ }^{* *}$ & $*$ & ${ }^{*}$ & ${ }^{*}$ & ${ }^{*}$ & $*$ & NS & NS \\
\hline
\end{tabular}

$\mathrm{N}=$ nitrogen; $\mathrm{Zn}=$ zinc; $\mathrm{KL}=$ kernel length; $\mathrm{KW}=$ kernel width; WAR = water absorption ratio; $\mathrm{PC}=$ protein content; $\mathrm{AC}=$ amylose content; $\mathrm{NS}=\mathrm{not}$ significant; , ${ }^{* *}$ : Significant at 0.05 and 0.01 , respectively. 
The maximum kernel protein contents were recorded with the application of $120 \mathrm{~N}+12 \mathrm{Zn}(\mathrm{kg} / \mathrm{ha})$ at site I while at site II with the application of $120 \mathrm{~N}+14 \mathrm{Zn}(\mathrm{kg} / \mathrm{ha}$; $\mathrm{Tab}$. 5). Poor $\mathrm{N}$ availability during flowering can severely affect rice protein contents (Perez et al., 1996). To attain high paddy yields with high protein contents, sufficient $\mathrm{N}$ supply is necessary (Perez et al., 1996). High protein contents at higher $N$ doses $(120 \mathrm{~kg}$ $\mathrm{N} / \mathrm{ha}$ ) indicate that plants were well supplied with $\mathrm{N}$ and sufficient $\mathrm{N}$ was mobilized from vegetative parts to grains (Samonte et al., 2006). This study is also in agreement with the findings of others (Schinir et al., 1990; Ali et al. 1992; Ahmad et al., 2009) who reported a significant improvement in kernel dimensions, kernel water absorption ratio, protein contents and milling quality of rice by optimum $\mathrm{N}$ fertilization. It was observed that both nitrogen and zinc treatments did not affect kernel amylose contents at both sites. It is interesting to note that kernel protein contents were higher at site II (Sheikhupura) as compared to site I (Sargodha) in almost all treatments (Tab. 5). While kernel amylose contents were slightly lower at site II than that of site I in most of the treatments. It seems that differences in soil factors such as $\mathrm{pH}$, organic matter and available phosphorus and potassium other than treatments at both experimental sites produced the contrasting differences in these two quality parameters.

\section{Acknowledgments}

Financial support from Higher Education Commission of Pakistan under Indigenous Scholarship Program is highly acknowledged.

\section{References}

Ahmad S, Hussain A, Ali H, Ahmad A (2005). Grain yield of transplanted rice (Oryza sativa L.) as influenced by plant density and nitrogen fertilization. Journal of Agriculture and Social Sciences 1:212-215.

Ahmad S, Zia-ul-Haq M, Ali H, Ahmad A, Khan MA, Khaliq M, Husnain Z, Hussain A, Hoogenboom G (2009). Morphological and quality parameters of Oryza sativa $\mathrm{L}$. as affected by population dynamics, nitrogen fertilization and irrigation regimes. Pak J Bot 41(3):1259-1269.

Ali A, Karim MA, Hussain G, Ali L, Ali SS, Majid A (1992). Rice grain quality as influenced by split application of nitrogen fertilizer. Int Rice Res Newslett 17(3):7-11.

Anonymous (2013). Economic Survey, Economic Affairs Division, Govt. Pakistan, Islamabad.

Ashraf M, Khalid A, Ali K (1999). Effect of seedling age and density on growth and yield of rice in saline soil. Pakistan Journal of Biological Sciences 2:860-862.

Chaudhry FM, Kausar MA, Rashid A (1977). Mechanism of nitrogen effect on zinc nutrition of flooded rice. Plant Soil 46(3):649-654.

Ding C, You J, Chen L, Wang S, Ding Y (2014). Nitrogen fertilizer increases spikelet number per panicle by enhancing cytokinin synthesis in rice. Plant Cell Rep 33(2):363-71.
Dobermann A, Cassman KG (2002). Plant nutrient management for enhanced productivity in intensive grain production systems of the United States and Asia. Plant Soil 247:153-175.

Fageria NK, Santos AB, Cutrim VA (2008). Dry matter and yield of lowland rice genotypes as influence by nitrogen fertilization. J Plant Nut 31(4):788-795.

Gao X, Hoffland E, Jan T, Cynthia S, Grant A, Zou C Zhang F (2012). Improving zinc bioavailability in transition from flooded to aerobic rice. A review. Agron Sustain Dev 32:465478.

Gebrekidan H, Seyoum M (2006). Effects of mineral N and P fertilizers on yield and yield components of flooded lowland rice on vertisols of Fogera Plain, Ethiopia. J Agr Rural Dev Trop 107 (2):161-176.

Genc Y, McDonald GK, Graham RD (2002). Critical deficiency concentration of zinc in barley genotypes differing in zinc efficiency and its relations to growth responses. J Plant Nutr 25:545-560.

Griggs BR, Norman RJ, Wilson CE, Slaton NA (2007). Ammonia volatilization and nitrogen uptake for conventional and conservation tilled dry-seeded, delayed-flood rice. Soil Sci Soc Am J 71:745-751.

Hafeez B, Khanif YM, Samsuri AW, Radziah O, Zakaria W, Saleem M (2010). Evaluation of Rice Genotypes for Zinc Efficiency under Acidic Flooded Condition. In 19 ${ }^{\text {th }}$ World Congress of Soil Science, Soil Solutions for a Changing World 1-6 August 2010, Brisbane, Australia.

Impa SM, Morete MJ, Ismail AM, Schulin R, Johnson-Beebout ES (2013). Zn uptake, translocation and grain $\mathrm{Zn}$ loading in rice (Oryza sativa L.) genotypes selected for $\mathrm{Zn}$ deficiency tolerance and high grain Zn. J Exp Bot 64(10):2739-2751.

Jacobs MB (1958). The chemical analysis of food and food products. Roberts AV Pub Co NY 32-35.

Juliano BO (1971). A simplized assay for milled rice amylase. Cereal Science Today 16(10):334-340.

Khan MU, Qasim M, Khan I (2007). Effect of Zn fertilizer on rice grown in different soils of Dera Ismail Khan. Sarhad Journal of Agriculture 23(4):1033-1040.

Khan R, Gurmani AR, Khan MS, Gurmani AH (2009). Residual, direct and cumulative effect of zinc application on wheat and rice yield under rice-wheat system. Soil and Environment 28(1):24-28.

Ladha JK, Pathak H, Krupnik TJ, Six J, van Kessel C (2005). Efficiency of fertilizer nitrogen in cereal production: retrospect's and prospects. Adv Agron 87:85-156.

Mae T (1997). Physiological nitrogen efficiency in rice: Nitrogen utilization, photosynthesis, and yield potential. Plant Soil 196:201-210.

Manzoor Z, Awan TH, Safdar ME, Ali RI, Ashraf MM, Ahmad $M$ (2006). Effect of nitrogen levels on yield and yield components of Basmati 2000. J Agri Res 44(2):115-120.

Maqsood M, Shehzad MA, Ali SNA, Iqbal M (2013). Rice cultures and nitrogen rate effects on yield and quality of rice (Oryza sativa L.) Turk J Agric For 37:665-673. 
379

Mengel K and Kirkby EA (2001). Principles of Plant Nutrition. 5th ed., Kluwer Academic Publishers, Dordrecht.

Mirzavand J (2007). Effects of soil application of zinc sulfate and immersing of seedling roots in zinc oxide suspension on yield and chemical composition of rice (Cv. Ghasrodashti). Iranian Journal of Soil and Waters Sciences 21(1):23-31.

Muthukumararaja TM, Sriramachandrasekharan MV (2012). Effect of zinc on yield, zinc nutrition and zinc use efficiency of lowland rice. International Journal of Agriculture Techechnology 8(2):551-561.

Norman RJ, Wilson CE, Slaton NA, Griggs BR, Bushong JT, Gbur EE (2009). Nitrogen fertilizer sources and timing before flooding dry-seeded, delayed-flood rice. Soil Sci Soc Am J 73:2184-2190.

Pandey N, Gupta M, Sharma CP (2001). Zinc efficiency affects pollen structure and viability in green gram (Vigna radiate $\mathrm{L}$. cv T-44). Geophytology 28:31-34.

Perez CM, Juliano OB, Liboon SP, Alcantara JM, Cassman KG (1996). Effects of late nitrogen fertilizer application on head rice yield, protein content, and grain quality of rice. Cereal Chem 73(5):556-560.

Qadar A (2002). Selecting rice genotypes tolerant to zinc deficiency and sodicity stresses. Differences in zinc, iron, manganese, copper, phosphorus concentrations, and phosphorus/zinc ratio in their leaves. J Plant Nutr 25:457473.

Quijano-Guerta C, Kirk GJD, Portugal AM, Bartolome VI, McLaren GC (2002). Tolerance of rice germplasm to zinc deficiency. Field Crops Res 76:123-130.

Rahman A, Yasin M, Akram M, Awan ZI (2002). Response of rice to zinc-application and different $\mathrm{N}$-sources in calcareous soil. Soil Conservation, Government of Punjab, Rawalpindi. National Agricultural Research Centre, Islamabad Quarterly. Science Vision 8(1):100-104.

Rashid A (1996). Secondary and micronutrient. In: A. Rashid and K. S. Memon, (eds). Soil Science. National Book Foundation, Islamabad.

Rashid A, Hussain F, Tahir M (1999). Alleviating zinc deficiency in transplanted flooded rice grown in alkaline soils of Pakistan. International Rice Research Notes (IRRI, Philippines) 24:3233.

Rashid A, Yasin M (2002). Zinc enrichment of the mat-type rice nursery. International Rice Research Notes (IRRI, Philippines) 27(2):32-33.
Reddy S (2004). Agronomy of field crops. Kalyani Publishers, New Delhi, India.

Saito M (1991). Soil management for the conservation of soil nitrogen. Extension Bulletins 341. Food and Fertilizer Technology Center, Taiwan.

Samonte SO, Wilson LT, Medley JC, Pinson SRM, McClung AM, Lales JS (2006). Nitrogen Utilization Efficiency: Relationships with Grain Yield, Grain Protein, and YieldRelated Traits in Rice. Agron J 98:168-176.

Sarwar N, Ali H, Ahmad A, Ullah E, Ahmad S, Mubeen K, Hill JE (2013). Water wise rice cultivation on calcareous soil with the addition of essential micronutrients. J Anim Plant Sci 23(1):244-250.

Schinir HF, Dingkuhn M, DeDatta SK, Mengal K, Faronilo JE (1990). Nitrogen fertilization of direct seeded vs transplanted rice. Nitrogen uptake photosynthesis, growth and yield. Crop Sci 30:1276-84.

Shivay YS, Kumar D, Prasad R (2005). Effects of zinc fertilization on physical grain quality of Basmati rice. International Rice Research Notes (IRRI, Philippines) 32(1):41-42.

Shivay YS, Prasad R, Rahal A (2010). Genotypic variation for productivity, zinc utilization efficiencies and kernel quality in aromatic rice under low available zinc conditions. J Plant Nut 33(12):1835-1848.

Singh M, Singh SP (1981). Effect of nitrogen and zinc on the yield of submerged rice and uptake of $\mathrm{N}$ and $\mathrm{Zn}$ on unlimed and limed soils. Plant Soil 62 (2):183-192.

Singh U, Ladha JK, Castillo EG, Punzalan G, Tirol-Padre A, Duqueza M (1998). Genotypic variation in nitrogen use efficiency in medium- and long-duration rice. Field Crop Res 58:35-53.

Tahir M, Kausar MA, Bhatti AS (1992). Micronutrient status and effectively ameliorating zinc deficiency in rice. Pakistan Journal of Scientific and Industrial Research 35:133-137.

Wang YY, Zhu B, Shi Y, Hu CS (2008). Effect of nitrogen fertilization on upland rice based on pot experiments. Commun Soil Sci Plan 39(11-12):1733-1749.

Wissuwa M, Ismail AM, Yanagihara S (2006). Effects of Zinc Deficiency on Rice Growth and Genetic Factors Contributing to Tolerance. Plant Physiol 142(2):731-741.

Wu G, Wilson LT, McClung AM (1998). Contribution of rice tillers to dry matter accumulation and yield. Agron J 90:317323. 